\title{
Automatic Melody Generation System with Extraction Feature
}

\author{
Kenichi Ida Member (Maebashi Institute of Technology, ida@maebashi-it.ac.jp) \\ Shinichi Kozuki Student Member (Maebashi Institute of Technology)
}

Keywords: automatic composition, combinatorial optimization problem, genetic algorithm

The history of an automatic composition by the computer starts during about half a century, and various methods are proposed today. One is that the system uses a general composition theory or system developer's composition knowledge, the other is that the system use the data extracted from existing music. The former is special system because of introducing the specific style. On the other hand, the latter is general system. It is because the analysis result of the music serves as a standard of music generation.

In this paper, we propose the melody generation system that can take user's favor based on the approach of the latter. Moreover, we propose the feature extraction method for the analysis of existing music, and try the offer of the best melody based on the acquired feature and the user's request.

The flow of the melody generation system is shown below. (1) A melody is inputted and a melody database is created. The melody which can be used is single melody and divided for each development of music (Reference Fig.1). (2) The melody used as an atmosphere base, a progression base and a rhythm is chosen from the melody database, respectively. The rhythm is used as a rhythm of an output melody. (3) An atmosphere feature is extracted from each note of the atmosphere base, and a progression feature is extracted from each development of the progression base. The atmosphere feature consists of two elements "pitch transition" and "time value relation", and these are used for local optimization of a melody. A rough atmosphere of the base can be made to reflect in a generation melody by the optimization. The progression feature consists of three elements of "upsurge", "smoothness", and "simplicity", and these are used for global optimization of a melody. A rough progression of the base can be made to reflect in a generation melody by the optimization. (4) User operation is arbitrarily added to the progression feature element. (5) GA searches for a melody corresponding to the rhythm so that both features are satisfied. In addition, the evaluation value of the melody is given from the satisfaction degree of the features. (6) The generation melody is saved in a database.

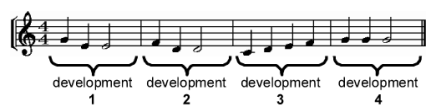

Fig. 1. Example of melody that can be used with this system
The actual example of melody generation is shown. Both the atmosphere base and the progression base are shown in Fig.2. A using rhythm is shown in Fig.3. The melody generated also as that of these conditions is shown in Fig.4. Moreover, the one that the user operation was added is shown in Fig.5. The results show that the proposed system can reproduce the feature of the base and reflect user operation.

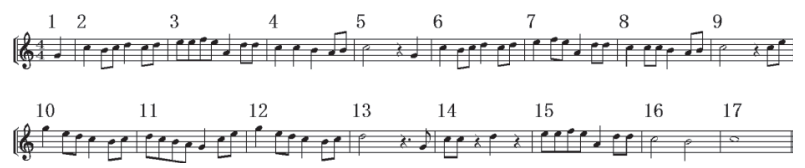

Fig. 2. Grandfather's Clock (both bases)

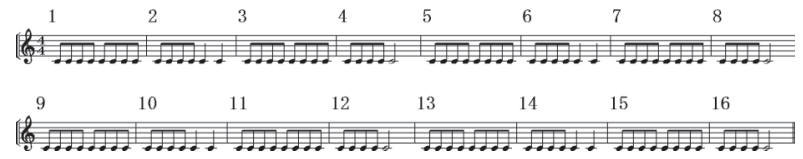

Fig. 3. Using rhythm

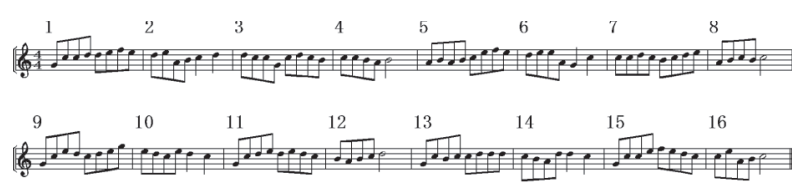

Fig. 4. Melody that reproduces the atmosphere and the progression

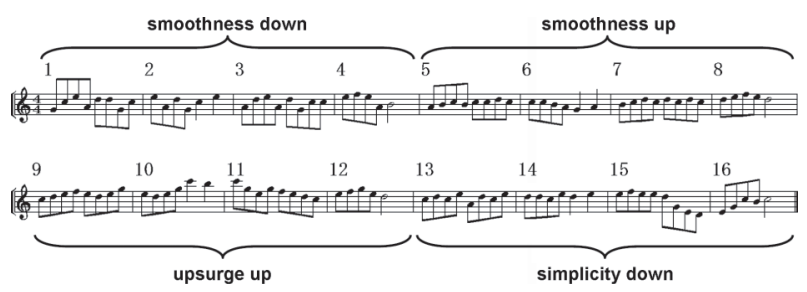

Fig. 5. The melody reorganized by user operation 


\title{
特徴抽出型メロディ自動生成システムの開発
}

\author{
正 員 井田 憲一* 学生員 上月 伸一*
}

\author{
Automatic Melody Generation System with Extraction Feature
}

Kenichi Ida*, Member, Shinichi Kozuki*, Student Member

In this paper, we propose the melody generation system with the analysis result of an existing melody. In addition, we introduce the device that takes user's favor in the system. The melody generation is done by pitch's being arranged best on the given rhythm. The best standard is decided by using the feature element extracted from existing music by proposed method. Moreover, user's favor is reflected in the best standard by operating some of the feature element in users. And, GA optimizes the pitch array based on the standard, and achieves the system.

キーワード：自動作曲，組合せ最適化問題，遺伝的アルゴリズム

Keywords: automatic composition, combinatorial optimization problem, genetic algorithm

\section{1. はじめに}

コンピュータによる自動作曲はおよそ半世紀前から始ま り (1), 今日ではさまざまな手法が考案されている。例えば, システム作成者がもつ知識ベースを用いて様々なスタイル の音楽を自動生成するシステム (2) や既存の音楽理論である 和声学の理論を用いてポップス向けメロディに和音を自動 付与するシステム (3) など, 特定の様式を利用するアプロー チである。これらは, 各々の方法論をそのまま取り入れる アプローチであるため, その領分に特化した作曲システム といえる。

また，既存メロディを一小節単位で格納したデータベー スからリズムと音高・コードパターンを取り出して合成す ることで作曲を行うシステム (4) や既存楽曲群の和音進行か ら得た情報ネットワークを用いてコード進行を作成する機 能を有するシステム ${ }^{(5)}$ など, 既存の楽曲から抽出したデー 夕を活用するアプローチがある。これらは, 既存の楽曲の 分析結果を楽曲生成に関する基準に取り入れることで分析 対象に応じた出力が行えるような, 汎用性を重視した作曲 システムである。これらのシステム(4)(5) は, データベース に蓄積したリズム, 音高・コードパターン, コード進行な どを部品とした一種の組合せ問題として捉え, 遺伝的アル ゴリズム (genetic algorithm: GA) により最適メロディ

\footnotetext{
$*$ 前橋工科大学大学院工学研究科

于 371-0816 前橋市上佐鳥町 460-1

Graduate School of Engineering, Maebashi Institute of Technology

460-1, Kamisadori-cho, Maebashi 371-0816
}

を生成しようとするものである。 更に，その中間に位置するアプローチとして，記憶パター ン更新機能を追加したカオスニューラルネットワークのふ るまいを利用して元メロディ群からメロディの連想を次々 に行い, 徐々にメロディを変化させつつ演奏し続けるシス テム(6) などがある。

二つめのアプローチに属する本論文では，リズムや音高 といった部品となるべき特徴要素をより細かく定義し，そ の抽出法を提案するとともに, 既存楽曲から抽出される簡 易な特徴のみを用いてメロディに関する音楽的な情報の再 構築を試みる。更に, 新たにユーザの好みや意思を取り入 れる仕組みを導入することにより, 多様化する音楽ニーズ に対応可能な汎用メロディ生成システムの開発を目指す。 本提案システムにおけるメロディ生成は, 事前に与えられ た音長列上で音高が最適な配列を成すことによって行われ る。その最適さ基準の決定に, 提案する特徵抽出法によっ て既存楽曲から抽出される特徵要素を用いる。また, その 特徵要素の一部をユーザが望む形に操作することでユーザ の好みを最適さ基準に反映可能にする。そして, その基準 に基づいて GA により音列の最適化を行うことでメロディ 生成を実現する。

なお，本論文は楽曲の様々なレベル†に対して特徽を抽出・ 適用することでユーザが真に望む楽曲を生成できるような 総合作曲システムの構築ための基礎研究である。

\footnotetext{
†メロディ,リズム，コード，曲構成，アレンジなど
} 


\section{2. メロディ生成システム}

〈2·1〉 メロディ生成システム全体の流れ 提案するメ ロディ生成システムの概念図を図 1 に，システム全体の流 れを以下に示す。ただし，メロディデータベースを必要と しない場合は, Step1 と Step6 省略することができる。 Step1：メロディデータベースの作成＼cjkstart好みのメロディ を入力し，メロディデータベースを作成する。

Step2：ベース選択メロディデータベースまたは直接 入力により，雲囲気ベースと曲進行ベースとなるメロディ とリズム（音長列）をそれぞれ選択する。

Step3 : 特徵抽出雲囲気ベースから雲囲気特徵, 曲進 行ベースから曲進行特徴をそれぞれ抽出する。

Step4: 特徵操作曲進行特徵パラメータに対し, 必要 であれば自由に手を加えることができる。

Step5：メロディ生成＼cjkstart選択された音長列上の音高が両 特徵データの条件を満たすようにGAによって最適化され， メロディが生成される。

Step6：メロディの保存＼cjkstart生成されたメロディをデータ ベースに保存する。

〈2・2〉 ユーザ操作部 ここでは，前節のメロデイ生成 システムの流れの中でユーザが操作可能な部分について概 説する。

（1）メロディデータベースの作成このシステムでは 既存のメロディをべースとして用いるため，最初にユーザ がメロディを直接入力してメロディデータベースを作成す る必要がある。本論文では，その入力可能なメロディを次 のように定義する。メロディは，音長・音高の值を一つず つもつような音符が配列を成し，この配列が曲展開番号に よって区切られている（図 2)。

ここで，曲展開番号とはメロディの展開（起承転結）の

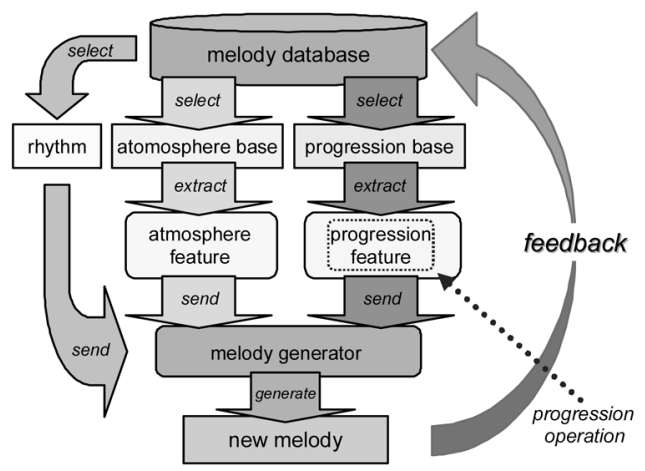

Fig. 1. Melody generation system

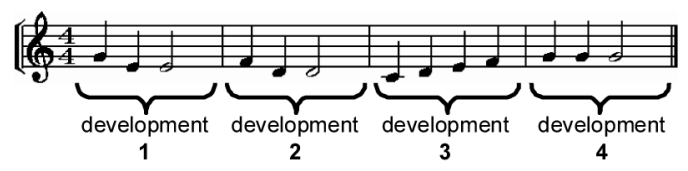

Fig. 2. Example of melody that can be used with this system
区切りを示すものとし，ユーザが自由に判断し設定するも のとする。この番号によってユーザが判断したメロディの 展開をシステムに把握させることになる。

（2）ベース選択ユーザは出力メロディの傾向を決め るために，雲囲気ベース・曲進行ベースとなるメロディと リズム（音長列）をそれぞれメロディデータベースから選 択する。選択された両ベースからそれぞれ特徴が抽出され， 選択された音長列はそのまま出力メロディ全体の音長列と なり, その各音長に対応する音高が抽出特徵を用いて最適 化されることでメロディが生成されるため，ここでのユー ザ選択が生成されるメロディの大まかな傾向を決定付ける ことになる。

（3）特徵操作 ユーザは自分好みのメロディを生成す るために, 抽出された曲進行特徴のパラメータを操作でき る。詳しくはく $3 \cdot 5$ 〉゙述べるが，この操作によって生成され るメロディに一定の指向性をもたせることもできる。

(4) メロディのフィードバック＼cjkstart生成されたメロディ はそれを鑑賞するだけでなくデータベース内に保存するこ とによって, 次回以降のメロディ生成に利用可能となる。

\section{3. 特徵抽出}

ここでは，メロディから抽出される特徴について述べる。 雲囲気ベースと曲進行ベースから抽出される特徴はそれぞ れ異なり，雲囲気ベースからはメロディのもつ雲囲気をメ ロディ生成時に再現できるような局所的な特徵（雲囲気特 徵）を，また曲進行ベースからはメロディを通しで聞いたと きにわかる起承転結を再現できるような大域的な特徵（曲 進行特徴）をそれぞれ抽出する。また，メロデイ生成に対 する汎用性を高めるため, 抽出する特徴はなるべく簡易な ものとする。

〈3・1 〉 雰囲気ベースからの特徵抽出 雲囲気ベース から抽出される雲囲気特徵は、『音高遷移』と『音長関係』 である。

『音高遷移』『音高遷移』は, 各音高に対する次の音 高との関係を表現したものである。その抽出例を図 3 に示 す。この例では，“ソ”という音高に対してその次の音であ る “ド”が読み込まれ，“ソ引ド”という『音高遷移』が抽出 されたことを示す。

抽出された『音高遷移』は, メロディ生成時に隣り合う 音高の関係を再現するために利用され，また自動的に音高 構成を維もする役割が与えられる。

『音長関係』『音長関係』は各音高に対応する音長の関 係を表現したものである。その抽出例を図 4 に示す。この 例では，“ソ”という音高に対してその音長である “四分音

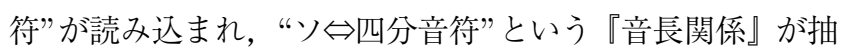
出されたことを示している。

抽出された『音長関係』は, どの音長以下の音符に対し て，どの音高の割り当てが許されるかを示す。例えば前出 の『音長関係』の抽出例では, 音高の「ソ」は「四分音符」 以下の音長をもつ音符に割り当てられることになる。そし 


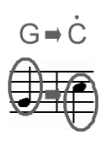

Fig. 3. Example of extracting "pitch transition"

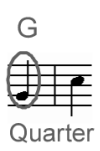

Fig. 4. Example of extracting

"time value relation"
てこれはメロディ生成時に音高と音長の対応関係を再現す るために利用される。

〈3・2〉 䨌囲気特徵の役割 メロディを生成するとき， どのような旋法を利用したかによってその雲囲気が大きく 変わる。この旋法の部分要素を『音高遷移』、音長関係』を 用いて生成メロデイに再現することが雲囲気特徵の役割で ある。メロディ生成時における雾囲気特徵の具体的な働き は,『音高遷移』がもつ音高構成を維持する役割によって旋 法の音階を再現し、『音高遷移』による隣り合う音高の関係 の再現と『音長関係』による音高と音長の対応関係の再現 によって音階を構成する各音高がもつであろう機能・役割 を簡易に再現することである。つまり，雲囲気特徵が全て の音符に対して満たされたメロディは，雲囲気ベースの雲 囲気をある程度再現することができるといえる。

$\langle 3 \cdot 3\rangle$ 音高遷移抽出法の追加・音高遷移拡張 しか し, 雲囲気特徵を完全に満たして出力されるメロディの自 由度は非常に低く，曲進行特徵を満たすメロディを生成す ることが困難となる場合がある。そこで, 雲囲気特徽によ る雲囲気の再現度合を少し犠牲にすることで, その問題点 を解決する。具体的には, 次に示す『音高遷移』の抽出法 の追加および『音高遷移』の拡張を行い, それをメロディ 生成に用いることができるようにする。

（1）音高遷移抽出法の追加 $<3 \cdot 1$ 節の『音高遷移』抽 出法（以後「基本抽出法」と呼ぶ）の他に,「強音抽出法」を 追加する。強音は聴覚上響きの強い音のことを指すが，本 論文では簡易的に表拍上の音符が強音であるとする。ここ での「強音抽出法」は, 各強音の音高に対する次の強音の 音高との関係を『音高遷移』として抽出する。

この「強音抽出法」によって抽出される『音高遷移』は 純粋に隣り合う音高の関係から抽出されたものではないの で，これを用いることで生成されるメロディの多様性を音 高構成が維持された状態で増すことができる。

音高遷移抽出法をまとめると以下のようになる。

\section{音高遷移抽出法}

-「基本抽出法」…隣り合う音高関係から『音高遷移』 を抽出（図 3)

-「強音抽出法」…隣り合う強音上での音高関係から 『音高遷移』を抽出

（2）音高遷移拡張『音高遷移』を拡張するため,「才 クターブ等価拡張」,「同音程拡張」, および「逆行拡張」を それぞれ導入する。

「オクターブ等価拡張」は各『音高遷移』に対して, その
オクターブ上とオクターブ下の音高関係を新たな『音高遷 移』として追加する。「同音程拡張」は各『音高遷移』に対 してその音程差を求め, 同じ音程差をもつ全ての音高関係 を音高構成が維持される範囲で追加する。「逆行拡張」は各 『音高遷移』に対して，その遷移を逆方向にした関係を追加 する。

こうして『音高遷移』がさらに導出され，メロディ生成 の自由度を音高構成を維持した状態でさらに増すことがで きる。

音高遷移拡張をまとめると以下のようになる。

\section{音高遷移拡張}

-「オクターブ等価拡張」…各抽出法によって抽出され た『音高遷移』に対して，その上下 1 オクターブ違い を追加

-「同音程拡張」…各抽出法によって抽出された『音高 遷移』に対して，その音程差と同じ音程差をもつ音高 構成内での音高関係全てを追加

-「逆行拡張」…各抽出法によって抽出された『音高遷 移』に対して，その前後関係を逆転させた音高関係を 追加

〈3・4〉曲進行ベースからの特徵抽出曲進行ベース の曲進行特徵は,『盛り上がり』,『滑らかさ』, および『単純 さ』の三つのパラメータで構成される。それらのパラメー 夕を表現するために, 各曲展開の音高列から,「音高平均」, $\lceil$ 最高音」, 「音程平均」, 「音程分散」, 「音高幅」, 「音高種類」, 「連続平行」,「連続上行」, および「連続下行」の 9 要素が それぞれ抽出される。

各要素の概要は以下のとおりである。

\section{曲進行特徵を表現するための要素}

-「音高平均」... 音高列中の音高の平均值

- 「最高音」 …音高列中の音高の最高值

-「音程平均」 $\cdots$ 音高列中の隣り合う音高間の音程の 平均值

-「音程分散」 $\cdots$ 音高列中の隣り合う音高間の音程の 分散值

-「音高幅」.. 音高列中の最高音と最低音との音高差

- 「音高種類」 ... 音高列を構成する音高の種類数

-「連続平行」.. 音高列中の音高の連続平行回数の平 均值

-「連続上行」.. 音高列中の音高の連続上行回数の平 均值

-「連続下行」.. 音高列中の音高の連続下行回数の平 均值

以下，上記要素を用いた『盛り上がり』、『滑らかさ』，お よび『単純さ』パラメータの表現方法について概説する。

(1)『盛り上がり』の表現 一般的に楽曲が最も盛り 上がる部分のことをサビと呼ぶが, 日本国内において最近 ヒットした歌謡曲を構成パート単位で調査 ${ }^{(7)}$ した結果, サ ビに向かって段々と音階は高くなり, サビでそれが最高と なることが示されている。また，そこに「最高音」が現れ 
ることが多いことも示されている。これらのことより，本 システムでは『盛り上がり』を「音高平均」,「最高音」の 2 要素で表現する。な㧍,「音高平均」,「最高音」の要素值が ともに他の曲展開のそれと比較して高いほど，その曲展開 のメロデイが相対的に盛り上がっていると判断できる。

(2)『滑らかさ』の表現＼cjkstart和声学においてメロデイが二 度音程で進行することを順次進行と呼び, これは滑らかな 進行であるとされている(8)。対して二度を超える動きをす る進行を跳躍進行と呼び，これは硬い進行であるとされて いる。これらのことより，本システムでは『滑らかさ』を 「音程平均」,「音程分散」の 2 要素で表現する。なお,「音程 平均」,「音程分散」の要素值がともに低いほど，その曲展 開のメロデイが滑らかであると判断できる。

（3）『単純さ』の表現』われわれが音楽を認知する場 合，全体的な手がかりとしてメロディの輪郭が用いられる ことが最もよく実証されている ${ }^{(9)}$ 。のことから，本シス テムに拈いては輪郭が単純であることを『単純さ』として 定義する。そして輪郭が単純であることを，輪郭の高低差 (「音高幅」), 輪郭を構成する音高の多様さ (「音高種類」), 輪郭の一定方向への連続移動（「連続平行」,「連続上行」,「連 続下行」）で表現する。なお，「音高幅」が小さく,「音高種 類」が少なく,「連続平行」,「連続上行」,「連続下行」が短い ほど，その曲展開のメロデイは単純であると判断できる。

$\langle 3 \cdot 5\rangle$ 曲展開特徵の役割 曲展開特徵を表現するた めの各要素は, 曲進行ベースの各曲展開から抽出される。 ここで曲展開間の区切りを与える曲展開番号はユーザが入 力するものであった $(\langle 2 \cdot 2\rangle(1))$ 。このことから，その各区 間ごとの何らかの相違をユーザはあらかじめ知覚している ということになる。この前提条件の下で，それらの相違を 分析するために実験的に用意したのが，『盛り上がり』，『滑 らかさ』，拉よび『単純さ』である。そしてこれらのパラ メータによって曲の起承転結を簡易に表現し，この構造を 生成メロデイに反映させることが曲展開特徵の役割である。 また，この『盛り上がり』『滑らかさ』『単純さ』パラメー 夕の值はユーザによって自由に操作することができるため, ユーザの搘好を形容詞レベルで曲の起承転結に反映させる ことができる。

\section{GA によるメロディ生成（音高列の最適化）}

本システムにおけるメロディ生成は，音符数 $I$ の任意の 音長列 $\left(r_{1}, r_{2}, \ldots, r_{I}\right)$ が入力されることで, 出力メロディ のリズムや総音符数が決定され，その各 $i$ 番目（メロディ 始端音符を 1 番，終端音符を $I$ 番と数える) の音符の音長 $r_{i}$ に対応する音高 $x_{i}$ を，その各曲展開から抽出された曲 進行特徵を考慮しつつ雲囲気特徵を用いて最適化すること により行われる。ただし，特徵を完全に満たすような最適 メロディの探索は非常に困難であるため, 近似解法の一つ である GA を用いてメロディの最適化を行う。

〈4・1〉 メロディの評価最適メロディ獲得に向けて GA が探索を行うためには，メロディの評価基準が必要で
ある。本システムではメロデイの評価值 $v$ を, 雲囲気特徵 不再現度 $v^{a}$ と曲進行特徵不再現度 $v^{p}$ を用いて (1) 式で求 める。この $v$ を最小化するのが最終的な目標となる。

$$
\min v=w^{a} v^{a}+w^{p} v^{p}
$$

ここで, $w^{a}$ と $w^{p}$ は次式を満たす非負の重みパラメータで ある。

$$
w^{a}+w^{p}=1 .
$$

雲囲気特徵不再現度 $v^{a}$ は，音高遷移特徵不再現度 $t_{i, i+1}$ の平均である第 1 項と, 音長関係不再現度 $u_{i}$ の平均であ る第 2 項からなる次式より求められる。

$$
v^{a}=\frac{w_{1}^{a}}{I-1} \sum_{i=1}^{I-1} t_{i, i+1}+\frac{w_{2}^{a}}{I} \sum_{i=1}^{I} u_{i} \ldots \ldots \ldots \ldots
$$

ここで, $w_{1}^{a}$ と $w_{2}^{a}$ は次式を満たす非負の重みパラメータで ある。

$$
w_{1}^{a}+w_{2}^{a}=1 .
$$

(3) 式第 1 項の音高遷移特徵不再現度 $t_{i, i+1}$ は, $x_{i}$ と $x_{i+1}$ の関係が, 前節 $(\langle 3 \cdot 3\rangle(1))$ の二つの抽出法 $(f=1$ : 基本 抽出，2:強音抽出）と, 同じく $(\langle 3 \cdot 3\rangle(2))$ の三つの拡張 法十拡張なし $(g=3$ :オクターブ等価拡張， 4 :同音程拡張， $5:$ :逆行拡張，及び $6:$ 拡張なし) の組合せから得られる『音 高遷移』に属するかを確認し，属する全ての組合せの中で 最も音高遷移特徵要素評価 $t_{f, g}^{i, i+1}$ が小さい值をとる。また, どこにも属さない場合は正の非常に大きなぺナルテイ值 $M$ をとる。すなわち，次式のようになる。

$$
t_{i, i+1}=\min \left\{t_{f, g}^{i, i+1} \mid f=1,2, g=3,4,5,6\right\}
$$

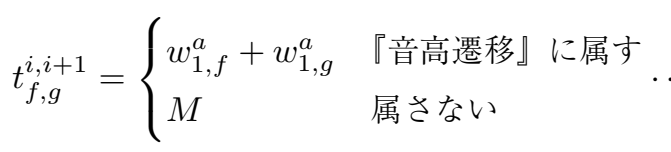

ここで, $w_{1, f}^{a}(\forall f), w_{1, g}^{a}(\forall g)$ は次式を満たす非負の重みパ ラメータである。

$$
\max _{1 \leq f \leq 2} w_{1, f}^{a}+\max _{3 \leq g \leq 6} w_{1, g}^{a}=1 \ldots \ldots \ldots \ldots \ldots
$$

ただし，(6) 式の $t_{f, g}^{i, i+1}$ では特に $w_{1,1}^{a}+w_{1,6}^{a}=0$ である ことが推奨される。これは，基本抽出 $(f=1)$ で拡張な し $(g=6)$ の『音高遷移』は, ベースの隣り合う音高の関 係をそのまま出力側に再現できる関係であるため，これに 対して減点することは望ましくないからである。

また，(3) 式第 2 項の音長関係不再現度 $u_{i}$ は, $x_{i}, r_{i}$ の 関係が『音長関係』に属する場合 0 , 属さない場合ペナル ティ值 $M$ をとる次式で表される。

$$
u_{i}= \begin{cases}0 & \text { 『音長関係』に属す } \\ M & \text { 属さない }\end{cases}
$$


曲進行特徵不再現度 $v^{p}$ は, 生成メロデイの曲進行特徵 $k$ $(k=1$ :盛り上がり，2:滑らかさ，3:単純さ）にそれぞれ対 応する構成要素 $l_{k}$ ( $l_{1}=1$ : 音高平均, 2 :最高音), $\left(l_{2}=1\right.$ : 音程平均, 2 : 音程分散), 及び $\left(l_{3}=1\right.$ : 音高幅, 2 : 音高種類, 3 :連続平行， 4 : 連続上行， 5 :連続下行）の不再現度 $v_{k, l_{k}}^{p}$ を 用いて次のように求められる。

$$
v^{p}=\sum_{k=1}^{3} w_{k}^{p} \sum_{l_{k}=1}^{L_{k}} w_{k, l_{k}}^{p} v_{k, l_{k}}^{p} \ldots \ldots \ldots \ldots \ldots \ldots \ldots
$$

ここで, $L_{k}$ は特徵 $k$ の構成要素数であり, 現システム では， $L_{1}=2, L_{2}=2, L_{3}=5$ の值をとる。また， $w_{k}^{p}(\forall k)$ と $w_{k, l_{k}}^{p}\left(\forall k, l_{k}\right)$ はそれぞれ $(10),(11)$ 式を満た す非負の重みパラメータである。

$$
\begin{gathered}
\sum_{k=1}^{3} w_{k}^{p}=1 \cdots \\
\sum_{l_{k}=1}^{L_{k}} w_{k, l_{k}}^{p}=1
\end{gathered}
$$

ただし, 曲進行特徵の要素不再現度 $v_{k, l_{k}}^{p}$ は, 生成メロ ディの各曲展開 $j(j=1,2, \cdots, J)$ から得られる各曲進 行特徵の各要素值 $c_{k, l_{k}, j}$ とその規定值 $b_{k, l_{k}, j}$ との差として (12) 式から得られる。ここでの規定值とは, ベースから読 み取った值またはユーザ設定の目標值である。

$$
v_{k, l_{k}}^{p}=\sum_{j=1}^{J} \frac{\left|c_{k, l_{k}, j}-b_{k, l_{k}, j}\right|}{d_{k, l_{k}}} \ldots \ldots \ldots \ldots \ldots
$$

また, $d_{k, l_{k}}$ は特徵 $k$ の要素 $l_{k}$ の減点度合の調整值であ り, 次式から求められる。

$$
d_{k, l_{k}}=\max _{1 \leq j \leq J} b_{k, l_{k}, j}-\min _{1 \leq j \leq J} b_{k, l_{k}, j}+1 \cdots \cdots
$$

ここで, (13) 式の第 1 項と第 2 項の演算から得られた值は, 各特長要素值の変動割合に応じた, $c_{k, l_{k}, j}$ と $b_{k, l_{k}, j}$ から得 られる特徴要素值の誤差に対する減点度合である。ただし， 第 1 項と第 2 項の演算結果が 0 となり, それをそのまま減 点度合として (12) 式に用いれば，0による除算が行われて しまうため, 各特徵要素の值が変動するときの最小単位と なる值を挙げた中での最大值である $1^{\dagger を}$ 第 3 項で加えて最 終的な減点度合としている。

〈4・2〉染色体表現 メロディを GA で扱うためにはメ ロディを染色体で表現する必要がある。本システムではメ ロディを構成する各音符がもつ音高の並び $\left(x_{1}, x_{2}, \ldots, x_{I}\right)$ を染色体とする。その長さは与えられた音長列の長さ，つま り曲全体の音符の数 $I$ と同一である。音高の表現は, MIDI 規格により扱えるオクターブ幅を考慮し, 最低を 0 , 最大を 119 とし，60 を MIDI 規格における C4（4 オクターブ目 のド）と定義する。他の音高は基準音から半音上がる（下

†音高種類数カウントである音高種類がこれに該当する。また，音 高種類以外の曲進行特徵要素の値は, $\langle 4 \cdot 2$ 節で示す音高の数值表現 法を用いて算出されるので，音高幅がこれに該当する。

\section{$\begin{array}{llllllll}C 4 & D 4 & F 4 & C 4 & E 4 & C 4 & G 4 & C 5\end{array}$ \begin{tabular}{l|l|l|l|l|l|}
\multicolumn{3}{|c|}{ coding } & \multicolumn{3}{c}{ con } \\
\hline 65 & 60 & 64 & 60 & 67 & 72 \\
\hline
\end{tabular} \\ pitch line \begin{tabular}{|l|l|l|l|l|l|l|l|}
60 & 62 & 65 & 60 & 64 & 60 & 67 & 72 \\
\hline
\end{tabular}}

Fig. 5. chromosome

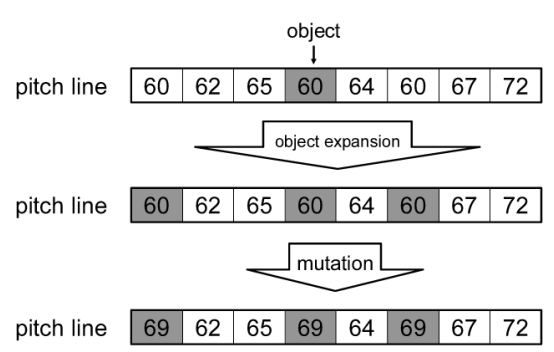

Fig. 6. mutation2

がる）ごとに值を+1（-1）したもので表現される（図 5)。 なお，初期染色体は，「雲囲気特徵である『音長関係』を 満たし，かついずれかの『音高遷移』を構成する音高の範 囲内の值をランダムに決定する」という生成規則を染色体 の全遺伝子座に適用して生成する。これを集団サイズ回繰 り返して初期集団とする。

〈4·3〉 遺伝的操作 GA は効率的に解を探索するた めに遺伝的操作を行う。遺伝的操作には，主に交叉や突然 変異が用いられる。本システムにおける遺伝的操作を次に 示す。

（1）交 叉 メロディ生成時に雲囲気特徵である『音 高遷移』が考慮されるため, 探索の進行に伴い染色体の隣 り合う遺伝子間の結びつきが強くなることが考えられる。 そのため，最も交叉点が少ない一点交叉を用いる。

この交叉が行われた場合, 新しく生成された子染色体と 親染色体の 4 個体間で生存選択を行う。生存するのは, 最 も評価值が良い個体と残りからランダムに選んだ個体の 2 個体である。この選択法を利用する理由は, 解を効率よく 更新することと母集団内での染色体の多様性を維持するこ ととのバランスをとるためである。

（2）突然変異 1 突然変異 1 は, 染色体内の遺伝子を 一つランダムに選び，その值を変更する。変更後の值は, 〈4・2〉で示した初期染色体の生成規則を適用する。これは突 然変異の探索効率を上げるためである。なお, 突然変異 1 が行われた場合, 親と子のうち評価值の良いほうが母集団 内に残る。

(3) 突然変異 2 突然変異 2 は, まず染色体内の遺伝子 を一つランダムに選び，その值を読み取る。次にそれと同 じ值をもつ全ての遺伝子を対象とし，值の変更を行う。変 更後の值は, 最初に選ばれた遺伝子に対して突然変異 1 と 同様の規則を用いることで決定される（図 6)。この突然変 異 2 は, 交叉や突然変異 1 によって操作されにくい「音高 幅」や「音高種類」の值を変動させることを目的として導 入している。ただし, 突然変異 2 が行われることで遺伝子 構造が大きく変化するため, 適用確率は交叉や突然変異 1 
のそれよりも非常に低く設定する必要がある。なお，突然 変異 2 が行われた場合，親と子のうち評価值が良いほうが 母集団内に残る。

\section{5. 実験}

〈5・1〉提案システムの有効性確認 提案システムの 有効性を確認するため, 雲囲気ベース・曲進行ベース共に “大きな古時計听の主旋律の一部をハ長調に移調したもの （図 7）を入力し，メロディを生成する。他の制約として， 音長列は図 8 (音符数 108）を用い, 曲展開の区切りはべー スメロディ・出力メロディ共に 4 小節ごとに与える（曲展 開数はそれぞれ四つ)。

GA のパラメータは，それぞれ集団サイズを 300 ，交叉 の適用確率を 1.000 , 突然変異 1 の適用確率を 1.000 , 突然 変異 2 の適用確率を 0.001 ，終了世代数を 2000 とした。

また，実験で用いる評価関数の各種重みを次のように設 定する。特徴不再現度重み $w^{a}, w^{p}$ の各值は, メロディの局 所的な整合性の保持を重視するため, $w^{a}=2 / 3, w^{p}=1 / 3$ とする。また, 雲囲気特徵要素に関する重み $w_{1}^{a}, w_{2}^{a}$ と曲進 行特徵とその要素に関する重み $w_{k}^{p}(\forall k), w_{k, l_{k}}^{p}\left(\forall k, l_{k}\right)$ は, 特徵の影響をそれぞれの重みの効果範囲内で均等に評価 に反映させるため, $w_{1}^{a}=w_{2}^{a}=1 / 2, w_{k}^{p}=1 / 3(\forall k)$, $w_{k, l_{k}}^{a}=1 / L_{k}\left(\forall k, l_{k}\right)$ とする。更に，音高遷移抽出または 拡張に関する重み $w_{1, f}^{a}(\forall f), w_{1, g}^{a}(\forall g)$ のうち, $w_{1,1}^{a}, w_{1,6}^{a}$ に関しては, 〈4·1 節にあるように $w_{1,1}^{a}=w_{1,6}^{a}=0.00$ と 設定する。その他の重みは，それぞれ $w_{1,2}^{a}=w_{1,5}^{a}=0.50$, $w_{1,3}^{a}=w_{1,4}^{a}=0.25$ としている。ただし, これら $w_{1,2}^{a}$, $w_{1,3}^{a}, \quad w_{1,4}^{a}, w_{1,5}^{a}$ の具体的な值の決定は, 事前の予備実験 を参考に行った。

（1）特徵抽出法の有効性検証 まず，提案特徵抽出法 によって抽出された特徵がほぼ全て再現されるとき，生成 されたメロディにベースの曲展開と雲囲気が再現されるこ とを検証するため，ユーザ操作を行わずにメロディ生成を 行う。その結果を図 9 に示す。

生成されたメロディの音高構成は “大きな古時計”と同じ になっていることはもちろん，このメロディからは“大きな 古時計”と同じような雲囲気が感じられる。この結果から， 雲囲気特徴である『音高遷移』と『音長関係』が有効に働 いたと確認できる。また，“大きな古時計”は曲展開ごとの 曲進行特徴の差異がさほど見られないが，それを生成メロ ディは再現できているため，曲進行特徵が有効に働いたと 確認できる。

（2）ユーザ操作によるメロディの改編＼cjkstart次に，ユーザ が曲進行特徵パラメー夕を操作することで, そのパラメー 夕に沿ったメロディ改編が成されることを確認する。変更 を行ったパラメータ以外はほぼべースを再現するという条 件のもと，曲展開 1 （1 小節～4 小節）の『滑らかさ』を最 大限減少させ，曲展開 2 ( 5 小節〜 8 小節）の『滑らかさ。

\footnotetext{
$\dagger$ Henry Clay Work : Grandfather's Clock
}

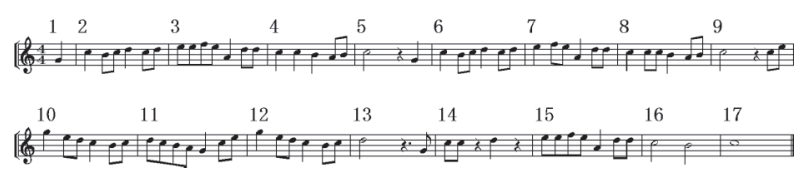

Fig. 7. Grandfather's Clock (both bases)

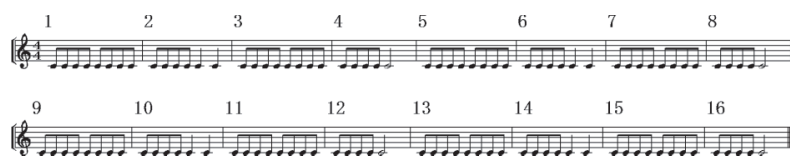

Fig. 8. Using rhythm

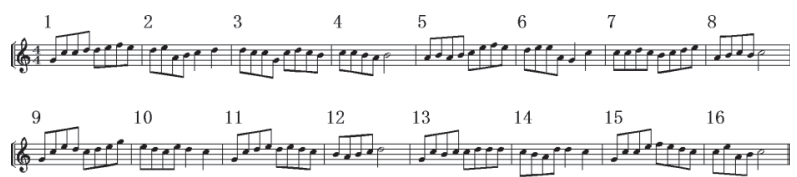

Fig. 9. Melody that reproduces the atmosphere and the progression

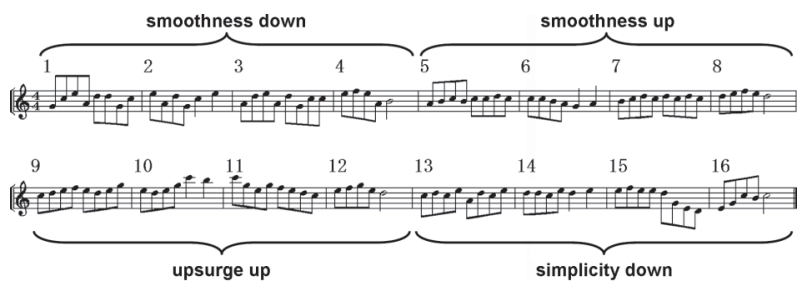

Fig. 10. The melody reorganized by user operation

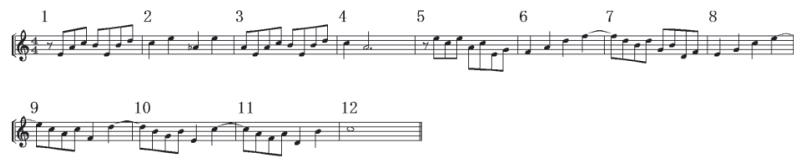

Fig. 11. Invention Op.13 (both bases)

を最大限増大させ，曲展開 3（9 小節～ 12 小節）の『盛り 上がり』を最大限増大させ，曲展開 4 （13 小節～16 小節） の『単純さ』を最大限減少させたメロディを生成した。そ の結果を図 10 に示す。

結果より，パラメータを操作することで各曲展開に大き な差異が与えられることが確認できた。具体的には，曲展 開 1 は音程の移動が激しく滑らかでないメロディとなり, 曲展開 2 は音程の変動が非常に小さく滑らかなメロディと なった。また，曲展開 3 は全体的に音高が高く盛り上がり， 曲展開 4 ではメロディラインが他の展開よりも全体的に大 きく動いていることが確認できる。これらのことより，曲 進行特徴パラメータの働きによって様々なメロディを生成 できる可能性が高いと思われる。

〈5・2〉 提案システムの沉用性確認前節とは異なる ベースでメロディを生成し，システムの汎用性を確かめる。 ここでは雲囲気ベース・曲進行ベース共に “インベンション 13 番勀を構成する旋律の一部（図 11）を入力する。他の 制約として，ベースの曲展開の区切りは 4 小節ごとに与え

†† Johann Sebastian Bach : Two-Part Invention No.13 


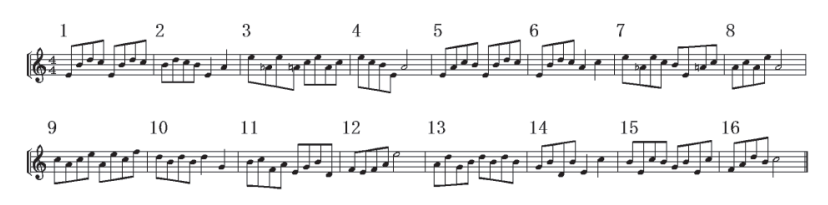

Fig. 12. Melody that reproduces the atmosphere and the progression (2)

る。また，音長列は図 8 （音符数 108）を用い，その曲展開 の区切りは 8 9 小節間と $12 \sim 13$ 小節間に与える（曲展開 数はそれぞれ三つ)。実験では，GA のパラメータと重みを 前節と同じにし，ベースから抽出された特徴をできる限り 再現するという条件下でメロディの生成を試みている。そ の結果を図 12 に示す。

この結果より，前節のベースから生成された結果とは異 なった雲囲気のメロディが生成されたことが分かる。この ことから，ベースに対応したメロディがそれぞれ生成でき ることが確認できる。

\section{6. おわりに}

本研究では，ユーザのニーズに対応可能な多様性のある メロディが生成できるシステムの開発を行った。実験結果 より，本システムはベースの雲囲気を残したメロディが生 成でき，さらにユーザがパラメー夕を設定することでメロ ディを好みに応じて作り変えることができるといえる。し かしながら，現システムでメロデイ生成時に用いることが できるパラメー夕は『盛り上がり』、『滑らかさ』，および 『単純さ』の 3 つのみであり, これだけでは表現しきれな いメロディの情報がまだまだ無数に存在すると考えられる。 例えば，一般的なメロデイには必ず見られる，短期的・長 期的な繰り返し構造なども現時点では表現することができ ない。

このような点を念頭に置き，メロデイを表現するために どのような情報が必要か，またそれをシステムにどのよう に組み込んでいくか，ということを今後とも慎重に検討し ていくことが必要である。

また，本システムでの評価関数は，大きく雲囲気特徵部 と曲進行特徵部に分かれ, それぞれが複数の階層構造をも ち, 多数の要素で構成され，そのすべての要素，階層ごと に重みを有している。したがって，重みの果たす役割は大 きく,この重みの取り方によって生成されるメロディも異 なることになる。

ユーザは，これらの重み（とベースメロディ）を自由に 設定することによって自分の好みにあったメロデイを生成 できるようになるが，自由度が大きいということはそれだ けユーザに負担を掛けることにもつながり，一概に良いこ ととはいえない。実際に利用する場合の利便性を考えれば, 嗜好パターンやプリセット值を用意するなど設定の簡易化 は必要と思われる。

ただ現時点では,「1.はじめに」でも述べたように，本研 究が総合作曲システム構築のための基礎研究であることを
考慮すれば，選択の幅（種々メロディの生成可能性）を広 くしておく方を優先し，その後のユーザインタフェース設 計時に利便性を検討しても遅くはないと考えている。 (平成 19 年 5 月 16 日受付, 平成 19 年 9 月 27 日再受付)

\section{文献}

（1）カーティス ローズ (平田圭二他訳)：コンピュータ音楽一歴史・テ クノロジー・アート, 東京電機大学出版局 (2001)

(2) 勝田哲司他:「音楽研究所」, http://www.asahi-net.or.jp/ HB9T$\mathrm{KTD} / \mathrm{music} / \mathrm{musj} . \mathrm{html}$ (2006)

(3) M. Miura, et al.: "AMOR: A System for Yielding Harmony to Given Melodies of Popular Styles", IPSJ Journal, Vol.46, No.5, pp.1176-1187 (2005-5) (in Japanese)

三浦雅展·青山容子·谷口 光・青井昭博 · 尾花 充・柳田益造 : 「ポップス系の旋律に対する和声付与システム：AMOR」, 情処学 論, Vol.46, No.5, pp.1176-1187 (2005-5)

（4）田中 健・外山 史・東海林健二：「遺伝的アルゴリズムを用いた メロディー進行とリズムの組合わせによる自動作曲」, 情処学研報 [音楽情報科学], Vol.2001, No.82, pp.43-48 (2001-8)

（5）山田拓志·椎塚久雄:「遺伝的アルゴリズムを用いた自動作曲について」, 情処学研報 [音楽情報科学], Vol.98, No.96, pp.7-14 (1998-10)

(6) M. Tokumaru, N. Muranaka, and S. Imanishi: "Continuous Expression System Repeating 'Memory and Forgetfulness' Application to a Music Composition System Using Chaos Neural Network with Rememorizing Patterns -", Journal of Japan Society for Fuzzy Theory and Intelligent Informatics, Vol.19, No.3, pp.299-312 (2007-6) (in Japanese) 德丸正考・村中德明·今西 茂:「「記憶と忘却」を繰り返し発想し続 けるシステム -記憶パターン更新型カオスニューラルネットワーク と作曲システムへの応用-」, 日本知能情報ファジイ学会誌, Vol.19, No.3, pp.299-312 (2007-6)

（7）石井一城:「ヒット曲の特徵」, 武蔵工業大学環境情報学部卒業研究 概要 $(2000)$

（8）須田佳典:創作田園地帯一和声学」, http://www.denen.org/wasei/ contents.xhtml (2006)

（9）ダイアナドイチュ (寺西立年他訳) : 音楽の心理学 (下), 西村書店 (1987)

井 田 憲 - (正員) 1952 年生。1976 年工学院大学卒業。1978

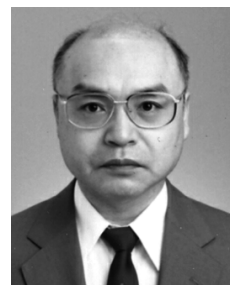
年同大学大学院修士課程修了。同年足利工業大学 助手。同大学講師, 助教授, 教授を経て, 1999 年 前橋工科大学教授, 現在に至る。工学博士。1988 1989 年米国 Univ. of Nebraska-Lincoln 客員研 究員。システム最適化法, 数值計算法, ファジィ 数理計画法, ソフトコンピューティング技法等の 研究・開発に従事。「線形計画」, 共立出版 (2003) 共著他。電子情報通信学会, 日本経営工学会, 日本知能情報ファジィ 学会, IIE 等各会員

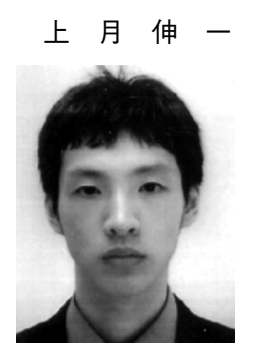

(学生員) 1983 年生。2006 年前橋工科大学工学 部情報工学科卒業。同年同大学大学院工学研究科 システム情報工学専攻博士前期課程入学, 現在に 至る。組合せ最適化, ソフトコンピューティング 技法等の研究・開発に従事。 